\title{
SISTEM PEMBERIAN KREDIT PADA KOPERASI SIMPAN PINJAM (KSP) CIPTA MULIA DESA BONDALEM
}

\author{
Kadek Anggan Parinata \\ Jurusan Akuntansi Program Diploma III, \\ Universitas Pendidikan Ganesha, Singaraja \\ angganpranata@gmail.com
}

\begin{abstract}
Abstrak
Penelitian ini bertujuan untuk mengetahui sistem pemberian kredit dan pada Koperasi Simpan Pinjam (KSP) Cipta Mulia Desa Bondalem. Data yang digunakan yaitu data kualitatif berupa formulir-formulir kredit, pedoman perkreditan dan struktur organisasi Koperasi Simpan Pinjam (KSP) Cipta Mulia Desa Bondalem dengan uraian tugasnya. Tehnik pengumpulan data yang digunakan adalah metode wawancara dan metode dokumentasi yang selanjutnya dianalisis dengan mengunakan analisis deskriptif kualitatif.

Hasil penelitian ini menunjukan sistem pemberian kredit pada Koperasi Simpan Pinjam (KSP) Cipta Mulia Desa Bondalem, yaitu Sistem pemberian kredit pada Koperasi Simpan Pinjam (KSP) Cipta Mulia Desa Bondalem diawali dengan kedatangan calon debitur ke bagian kredit untuk meminta formulir surat permohonan pinjaman dan diisi dengan syarat yang telah ditentukan. Kemudian bagian manajer akan melakukan survey ke lokasi calon debitur untuk mengetahui usaha yang dijalankan oleh calon debitur dan mengetahui apakah calon debitur tersebut sanggup dalam melunasi kewajibannya.
\end{abstract}

Kata kunci : Sistem Pemberian Kredit,

\section{Abstract}

This study aims to determine the system of credit and the Savings and Loans Cooperative (KSP) Cipta Mulia village of Bondalem. The data used is qualitative data in the form of the forms of credit, credit guidelines and organizational structure of Credit Unions (KSP) Cipta Mulia village Bondalem with job descriptions. Data collection techniques used were interviews and documentation methods were further analyzed by using qualitative descriptive analysis.

These results indicate the system of credit in the Cooperative Savings and Loans (KSP) Cipta Mulia village of Bondalem, the system credits, Credit Unions (KSP) Cipta Mulia village Bondalem begins with the arrival of prospective borrowers to the credit department to request a form letter loan application and filled on the condition that has been determined. Then the manager will conduct a survey to determine the location of the prospective borrowers to business carried on by debtor and determine whether the debtor is able to repay its obligations. Credit department will collect data, assess collateral and analyze the loan application. Then the borrower will bring the letters to the cashier to be made Evidence Accounts Payable, Cash Evidence Log (BKM), Proof of Cash Out (BKK), and continued with the delivery of money to the borrower. The accounting will record transactions arising from the evidence incoming cash, cash out the evidence, and evidence of disbursements of loans for the journal is subsequently made up with the financial statements.

Keyword: Lending Systems, 


\section{Pendahuluan}

Koperasi merupakan lembaga keuangan bukan bank yang dibentuk untuk mengelola dana yang dihimpun oleh anggota guna membiayai kebutuhan koperasi dan keanggotaanya. Dana tersebut dihimpun melalui simpanan pokok, simpanan wajib dan simpanan sukarela serta kegiatan usaha lainnya yang dilakukan oleh koperasi untuk mendapatkan Sisa Hasil Usaha (SHU) yang besar. Dana yang dihimpun koperasi tersebut dikelola oleh manajemen koperasi, selanjutnya dapat digunakan untuk pemberdayaan, perkembangan dan usaha lainnya serta membantu anggota melalui pinjaman dengan ketentuan yang diatur dalam Rapat Anggota Tahunan (RAT). Dana tersebut disalurkan kepada yang memenuhi syarat untuk memperoleh kredit, seperti anggota koperasi dan masyarakat lain yang dianggap layak memperoleh kredit dari koperasi.Koperasi simpan pinjam didirikan bertujuan untuk memberi kesempatan kepada anggotanya untuk memperoleh pinjaman dengan persyaratan mudah dan bunga yang relatif ringan.

Koperasi simpan pinjam juga berusaha untuk mencegah para anggotanya agar tidak terlibat dalam hutang rentenir, dengan jalan meningkatkan tabungan dan mengatur pemberian pinjaman uang dengan bunga yang serendah-rendahnya, koperasi simpan pinjam menghimpun dana dari para anggotanya yang kemudian menyalurkan kembali dana tersebut kepada para anggotanya. Sebagai lembaga keuangan bukan bank yang berfungsi menghimpun dan menyalurkan dana dalam bentuk pinjaman atau kredit, koperasi simpan pinjam berusaha memberikan kemudahan dalam layanan pemberian kredit. Namun pada umumnya masyarakat masih kurang memahami tata cara dan syarat pemberian kredit.Kata kredit berasal dari bahasa latin credere yang artinya kepercayaan. Maksud dari percaya, bagi pemberi kredit adalah percaya kepada penerima kredit bahwa kredit yang disalurkan pasti akan dikembalikan sesuai dengan perjanjian. Sedangkan bagi penerima kredit mempunyai kewajiban membayar sesuai jangka waktu yang telah disepakati. Dalam masyarakat, pengertian kredit sering disamakan dengan pinjaman, artinya bila seseorang mendapat kredit berarti mendapat pinjaman. Untuk meyakinkan calon nasabah benar-benar dapat dipercaya maka harus menganalisa kredit terlebih dahulu, yang mencakup latar belakang nasabah, prospek usahanya, jaminan yang diberikan serta faktor-faktor pendukung lainnya. Tujuan analisa ini yaitu untuk meyakinkan bahwa kredit yang diberikan benar-benar aman, sehingga bisa memperlancar proses pemberian kredit, dan mencegah terjadinya kredit macet. Kriteria yang harus diperhatikan yaitu mencakup 5C yang meliputi Character, Capacity, Capital, Collateral, dan Condition. Dalam pelaksanaan kegiatannya juga perlu melalui prosedur pemberian kredit yang baik, yaitu dengan melalui tahapan-tahapan, diantaranya permohonan pemberian kredit, keputusan persetujuan atau penolakan permohonan, perjanjian kredit, pencairan kredit, administrasi, pengawasan dan pembinaan, serta pelunasan kredit. Hal ini juga didasarkan atas azas-azas dan kebijakan yang tentunya memberikan keuntungan bagi kedua belah pihak. Sedangkan sistem itu sendiri merupakan suatu jaringan prosedur yang dibuat menurut pola yang terpadu untuk melaksanakan kegiatan pokok perusahaan.

Berdasarkan latar belakang tersebut, dapat dirumuskan masalah penelitian yaitu, "Bagaimana Sistem Pemberian Kredit yang diberlakukan pada Koperasi Simpan Pinjam (KSP) Cipta Mulia Desa Bondalem?"

\section{Metode Penelitian}

Sebelum melakukan penelitian, hal pertama yang harus dilakukan yaitu menentukan lokasi penelitian dimana lokasi penelitian yang dipilih penulis adalah Koperasi Simpan Pinjam (KSP) Cipta Mulia Desa Bondalem yang beralamat di Jalan Raya Singaraja Amlapura, Kecamatan Tejakula Kabupaten Buleleng. Setelah lokasi penelitian ditentukan barulah penulis melihat hal-hal apa saja yang terjadi pada Koperasi Simpan Pinjam (KSP) Cipta Mulia Desa Bondalem terkait dengan sistem pemberian kredit. Setelah itu penulis dapat merumuskan masalah dari penelitian yang akan diambil lalu membuat kajian teori dimana dari kajian teori inilah penulis dapat mengetahui datadata apa saja yang dibutuhkan. Data yang digunakan dalam penelitian ini berupa data kualitatif yang berasal dari hasil wawancara penulis dengan Pimpinan Koperasi Simpan 
Pinjam (KSP) Cipta Mulia Desa Bondalem. Data yang diperoleh kemudian dianalisis menggunakan analisis deskriptif kualitatif. Dari pengolahan data tersebut, penulis mendapatkan hasil penelitian dimana drai hasil penelitian inilah penulis dapat menarik kesimpulan mengenai sistem pemberian kredit yang diterapkan oleh Koperasi Simpan Pinjam (KSP) Cipta Mulia Desa Bondalem.

\section{Hasil dan Pembahasan}

Dalam penelitian ini dapat diketahui bahwa sistem pemberian kredit diawali dengan kedatangan calon peminjam ke bagian kredit untuk meminta Formulir Permohonan Pinjaman dan diisi dengan syarat yang telah dipenuhi maka calon peminjam dapat mengajukan Formulir Permohonan Pinjaman ke bagian kredit. Calon debitur juga harus menyerahkan jaminan berupa STNK motor untuk pinjaman diatas Rp 1.000.000,00 sampai Rp 10.000.000,00, dan pinjaman dibawah $\mathrm{Rp} 1.000 .000,00$ calon debitur tidak perlu menyerahkan jaminan karena tabungan tersebut akan menjadi jaminan sedangkan peminajm yang tabungannya dibawah $\mathrm{Rp} 1.000 .000,00$ harus menyerahkan jaminan. Kemudian bagian Manajer akan melakukan survei ke lokasi calon debitur untuk mengetahui usaha yang dijalankan oleh calon debitur dan mengetahui apakah calon debitur tersebut sanggup dalam melunasi kewajibannya. Manajer juga akan mempertimbangkan jaminan yang diberikan oleh calon debitur dengan pinjaman yang di inginkan oleh peminjam, apakah sesuai jaminan yang diberikan dengan besarnya pinjaman yang diinginkan oleh calon debitur. Setelah survey dilakukan dan diotorisasi oleh bagian manajer semua data tersebut akan dikumpulkan dibagian kredit. Bagian kredit lalu akan mengumpulkan data, menilai jaminan dan menganalisis permohonan pinjaman tersebut. Setelah permohonan tersebut disetujui maka akan dibuatkan Surat Perjanjian Pinjaman, Surat Kuasa dan Surat Pernyataan masing-masing rangkap dua. Lembar pertama akan dibawa oleh peminjam dan lembar kedua disimpan oleh bagian kredit sebagai arsip.

Setelah Surat Perjanjian Pinjaman, Surat Kuasa, dan Surat pernyataan diotorisasi oleh manajer, surat-surat itu pun harus diotorisasikan oleh peminjam. Kemudian peminjam akan membawa surat-surat tersebut kebagian kasir, lalu oleh bagian kasir dibuatkan Bukti Pengeluaran Kas, Bukti Kas Masuk, Bukti Kas Keluar, dan dilanjutkan dengan penyerahan uang kepada penerima pinjaman serta dipotong biaya administrasi. Setelah kredit dicairkan maka bagian kredit akan menyerahkan bukti kas masuk, bukti kas keluar, bukti pengeluaran pinjaman kebagian accounting. Bagian accounting akan mencatat transaksi yang timbul dari bukti kas masuk, bukti kas keluar, dan bukti pengeluaran pinjaman untuk selanjutnya dibuatkan jurnal sampai dengan laporan keuangan.

Dilihat dari pembahasan diatas secara umum Sistem Pemberian Kredit pada Koperasi Simpan Pinjam (KSP) Cipta Mulia Desa Bondalem sangat baik. Salah satu usaha yang harus ditempuh oleh pihak Koperasi untuk menekan jumlah kredit macet adalah menjalankan prinsip $5 \mathrm{C}$ yaitu :

1. Character (Kepribadian)

Yaitu menyangkut kepribadian, sifat/watak, kejujuran seseorang dalam hal ini adalah debitur. Tujuannya adalah untuk memberikan keyakinan kepada Bank bahwa, sifat/watak dari orang-orang yang akan diberikan kredit benar-benar dipercaya. Keyakinan ini tercermin dari latar belakang si nasabah baik yang bersifat latar belakang pekerjaan maupun yang bersifat pribadi seseorang yang memilki karakter baik yang memiliki kejujuran dalam membuat pekerjaan untuk memenuhi kewajibannya.

2. Capacity (Kemampuan)

Yaitu yang menyangkut kemampuan atas kesanggupan dalam membayar kewajiban-kewajibannya tepat pada waktunya. Kesanggupan dapat di ukur dengan data financial tahun yang lalu.

3. Capital (Modal) 
Untuk mengetahui sumber-sumber pembiayaan yang dimilki nasabah terhadap usaha yang akan dibiayai oleh bank, yaitu menyangkut besar kecilnya pertimbangan antara jumlah hutang dan modal kerja.

4. Condition of Economic (Kondisi Ekonomi)

Yaitu kondisi atas ekonomi harus diperhatikan dalam pertimbangan pemberian kredit terutama dalam hubungannya dengan sektor usaha calon peminjam

5. Collateral (Jaminan)

Yaitu menunjukan jaminan yang diberikan atas kredit yang diterima. Jaminan tersebut dapat berupa barang, harta bergerak, ataupun harta tidak bergerak. Jaminan hendaknya melebihi jumlah kredit yang diberikan.

\section{Simpulan dan Saran}

Adapun kesimpulan yang dapat diambil yaitu, sistem pemberian kredit pada Koperasi Simpan Pinjam (KSP) Cipta Mulia Desa Bondalem diawali dengan kedatangan calon debitur ke bagian kredit untuk meminta formulir surat permohonan pinjaman dan diisi dengan syarat yang telah ditentukan. Kemudian bagian manajer akan melakukan survey ke lokasi calon debitur untuk mengetahui usaha yang dijalankan oleh calon debitur dan mengetahui apakah calon debitur tersebut sanggup dalam melunasi kewajibannya. Bagian kredit akan mengumpulkan data, menilai jaminan dan menganalisis permohonan pinjaman tersebut. Kemudian peminjam akan membawa surat-surat tersebut ke bagian kasir untuk dibuatkan Bukti Pengeluaran Kas, Bukti Kas Masuk (BKM), Bukti Kas Keluar (BKK), serta dilanjutkan dengan penyerahan uang kepada penerima pinjaman. Bagian accounting akan mencatat transaksi yang timbul dari bukti kas masuk, bukti kas keluar, dan bukti pengeluaran pinjaman untuk selanjutnya dibuatkan jurnal sampai dengan laporan keuangan.

Sedangkan saran yang dapat disampaikan adalah dalam pengimplementasikan prosedur dan sistem pemberian kredit pada Koperasi Simpan Pinjam (KSP) Cipta Mulia Desa Bondalem agar berjalan lebih baik lagi, perlu ditingkatkan lagi dengan cara tetap mengikuti ketentuan-ketentuan dari peraturan yang ada, sehingga tata cara penyaluran kredit tetap konsisten sehingga tidak menimbulkan masalah dimasa mendatang misalnya adanya kredit macet. Selain itu Kepala Koperasi lebih memotivasi staf pegawai Koperasi terutama bagian-bagian yang terlibat dalam sistem pemberian kredit agar dalam melakukan analisis pemberian kredit bisa lebih ketat lagi, tetapi tidak menghambat pencairan kredit agar bisa meminimalisir kredit macet. Misalnya dengan kontrol yang dilakukan berjenjang dari seluruh bagian yang terlibat dalam proses pemberian kredit.

\section{DAFTAR PUSTAKA}

Arifin sitio (2001:1) pengertian Koperasi tersedia pada https://arifinsitio26.wordpress.com/2011/10/09/pengertian-koperasi, diakses tgl 7 April 2016.

Arikunto, Suharismi.2005. Manajemen Penelitian. Edisi Revisi.Jakarta.PT Rineka Cipta

Cole (dalamBaridwan,1991:3 ) Pengertian kredit tersedia pada http://pckom.blogspot.co.id/2009/07/sistem-informasi, di akses tgl 7 April 2016

Kasmir (2002:2016) Fungsi Kredit tersedia pada http://www.kajianpustaka.com/2013/02/pengertian-unsur-dan-fungsi-kredit.html, di akses pada tgl 4 April 2016-04-16

Kasmir (2010) pengertian Kredit tersedia Pada http://mutiaralumpur.blogspot.co.id/2010/01/pengertian-kredit.html, diakses tgl 6 April 2016

Mulyadi. 2001. Sistem Akuntansi. Edisi ke 3 Bagian Penerbitan Sekolah Tinggi ilmu Ekonomi YKPN Yogjakarta 
Vol. 10 NO.1 JULI 2019

p-ISSN:2338-6177

Rachmat Firdaus, dkk. 1999. Dasar-dasar perkreditan. Edisi 4. Jakarta PT Gramedia Pustaka Utama 